m

ن

ธิ

ำ

@

일

\title{
Bondyho bratislavská Epizóda
} Radoslav Passia

\author{
PASSIA, R.: Bondy's Bratislava Episode
}

SLOVENSKÁ LITERATÚRA, vol. 68, 2021, no. 3, pp. 304-313

DOI: https://doi.org/10.31577/slovlit.2021.68.3.9

ORCID ID: 0000-0001-7045-7901

Key words: Egon Bondy, Bratislava, space, urban text, empty spaces

The introductory section of the article reconstructs the arrival of the Czech writer, philosopher and foremost member of underground culture, Egon Bondy (1930-2007) to Bratislava in 1993. There he became part of the city's intellectual and cultural (literary, musical and artistic) life. The novella Epizóda'96 [Episode '96] Bondy wrote in Slovak is an important contribution to the literary identity of the city. The article interprets the close relationship between Bondy's narrator and space and also looks at the central topoi present in Bondy's portrayal of Bratislava. He presents the city via "emptiness". Diachronically, this means putting into spotlight some of the key episodes (unknown territories) of the weakened historical memory of the city (life and work of the sculptor F.X. Messerschmidt and the fates of the Jewish community). Synchronically, the author focuses on the structure of the city formed by socialist planning and on the empty spaces as natural spaces that to a great extent determine Bratislava's genius loci (the Danube, the Little Carpathians).

\section{Klúčové slová: Egon Bondy, Bratislava, priestor, mestský text, prázdne miesta}

„Mesto je naozaj heterogénne. Velmi heterogénne.“

(Egon Bondy: Epizóda '96)

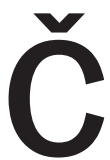

eský básnik, prozaik a filozof Egon Bondy, vlastným menom Zbyněk Fišer (1930 - 2007), žil v Bratislave od roku 1993 až do svojej smrti v roku 2007. Smer a motivácia jeho prest'ahovania by mohli byt' predmetom samostatnej úvahy, v ktorej by sme analyzovali toto gesto v kontexte rozhodujúcich spoločensko-politických udalostí v Československu koncom osemdesiatych 
a v prvej polovici devätdesiatych rokov 20. storočia, teda pádu totalitného režimu 305 v roku 1989 a zániku federácie na prelome rokov 1992 a 1993, ale aj jeho osobných životných peripetií vo vzt'ahu k českému undergroundu a prednovembrovej komunistickej moci. Na túto vec prevažuje názor, že ked' po roku 1989 vyšla najavo Bondyho opakovaná a dlhoročná spolupráca so Štátnou bezpečnost'ou, natol'ko to oslabilo jeho pozíciu a porevolučné perspektívy v pražskom prostredí, že sa rozhodol z mesta odstahovat. ${ }^{1}$

$\mathrm{V}$ českom samizdatovo-undergroundovom kultúrnom okruhu bol pritom legendárnou postavou, dokladom môžu byt' početné umelecké reflexie aj spomienky súčasníkov. Výberovo spomeňme aspoň Magorův zápisník Ivana Martina Jirousa, Vzpomínky malostranské lekárky a Bondyho dôverníčky Marie Klečackej-Beyly alebo dokumentárny film režisérov Tomáša Mazala a Pabla de Sax (občianskym menom Pavel Veselý) z roku 1985 My žijeme v Praze..., kde je E. Bondy v úvodných titulkoch označený ako „underground superstar“. Praha sa do názvu nedostala náhodou. Vo filme sprevádza Bondy diváka „svojimi“ miestami v českej metropole, $\mathrm{v}$ preňho charakteristickej bizarnej symbióze s rôznorodými osobnými a spoločenskými reflexiami komentuje jej topografiu a urbanizmus v kontexte radikálnych dobových zásahov do historických mestských štruktúr. Je hlavnou postavou filmu, ale ako rozprávač v ňom do popredia exponuje konkrétne urbánne prostredie ako nevyhnutný substrát istého životného štýlu, ktorého je sám zosobnením. Film až inštruktážne ukazuje Bondyho vnímanie mesta ako živého, „citlivého“2 organizmu, nevyhnutne spojeného s jeho „,čitatel'om“. Chôdza pražskými ulicami, ich neustále „,prešlapávanie“, 3 je rovnako nástrojom kultúrno-historickej, spoločensko-politickej aj semiotickej interpretácie mesta ako aktom intímnej sebatvorby. ${ }^{4}$

Svedectvo o základnom priestorovom rozvrhu Bondyho života v Prahe ${ }^{5}$ vo vztahu k jeho kultúrnym záujmom a aktivitám v undergroundovom hnutí podala tiež M. Klečacká-Beyly, ktorá ho v zhode s profilom z filmu My žijeme v Pra$z e .$. vidí aj ako zasväteného pražského flanéra: „Doplňkem našeho programu byly mistopisné vycházky po Praze a pražském okolí, při nichž Fišer exceloval udivujícími a podrobnými znalostmi“ (Klečacká-Beyly 2008: 88).

V devät'desiatych rokoch prevládal v pohybe intelektuálnych a ekonomických elít, ale i menej kvalifikovanej pracovnej sily, zjavne opačný migračný vektor, než si zvolil Bondy. Česko nastúpilo na nádejnú cestu postkomunistickej

1 Česká emigrantka, lekárka M. Klečacká-Beyly (narodená 1946) vo svojej autobiografickej spomienkovej knihe, tematicky výrazne centrovanej na jej dlhoročný priatel'ský vztah s E. Bondym a jeho životnou družkou Juliou Novákovou, uvádza popri spomenutom politickom kontexte ako výrazný podnet na prest'ahovanie tejto dvojice do Bratislavy fakt, že J. Nováková v tomto meste strávila v mladosti niekol'ko rokov. V Bratislave vtedy žila so svojím manželom, stavebným inžinierom Vojtěchom Novákom (Klečacká-Beyly 2008: 67).

2 K pojmu pozri Hodrová 2006.

3 Príkladom sú Bondyho slová z úvodnej časti filmu: „My s Julií jsme bydleli v našem nádherném paláci a vyšli jsme si na procházku, znovu už po desetitisíci nebo sto tisíci si prohlídli Prahu, počínaje naší Nerudovkou“ (Tomáš Mazal - Pablo de Sax: Myžijeme v Praze..., ČSSR 1985/75 minút).

4 Filmových dokumentov o Bondym vzniklo viac, predovšetkým dvojdielny dokument Fišer alias Bondy (1999, 2000, režisér Jordi Niubó), v slovenskej produkcii napríklad televízny film Egon Bondy režiséra Martina Hanzlíčka (2005).

5 E. Bondy s J. Novákovou bývali v byte na Nerudovej 51 na Malej Strane (Klečacká-Beyly 2008: 64 a nasledujúce). 
306 transformácie, Slovensko žilo v mečiarizme, jeho prítažlivost' v medzinárodnom kontexte bola nízka, krajinu a jej hlavné mesto ludia skôr opúštali a smerovali na západ. ${ }^{6}$ Aj preto sa pristahovanie Bondyho do Bratislavy a získanie slovenského občianstva vnímalo ako polemické politické gesto. Ako osobnosti dobre známej v miestnych umeleckých kruhoch, no zároveň bez priamych negatívnych konotácií spojených s predošlým životom, sa mu tu dostalo primeranej pozornosti.7 Bondyho popularita sa s vel'kou pravdepodobnostou neopierala o poznanie jeho filozofického a básnického diela, korene mala skôr v populárnejších kultúrnych aktivitách. Na Slovensku bol známy ako jeden z „nežných barbarov“, zachytených v rovnomennej novele Bohumila Hrabala, respektíve vo filmovej adaptácii novely od režiséra Petra Kolihu, aj ako textár hudobnej formácie The Plastic People of the Universe. ${ }^{8}$

Pokial' ide o spoločenskú a intelektuálnu akceptáciu, Bondy bol v Bratislave $\mathrm{v}$ tomto období v relatívne prajnom prostredí. Prednášal východnú filozofiu na univerzitách $\mathrm{v}$ Bratislave a Prešove a okrem účasti na literárnych podujatiach sa aktívne zapájal do kultúrneho života aj v menej očakávaných oblastiach. Účinkoval v hudobnej formácii Požoň sentimentál, s ktorou vytvoril projekt Urban Songs (200o) rozvíjajúci tradície mestského hudobného folklóru, bol tiež autorom libreta opery Mareka Piačeka Posledný let-dvanást' pohl'adov na M. R. Š. (2001). ${ }^{9}$ Živo komunikoval s výtvarnou obcou - stal sa dokonca vizuálnym námetom diel známych slovenských výtvarníkov. ${ }^{10}$ Treba dodat', že Bondyho kontakty so slovenským prostredím sa nezačali prestahovaním do Bratislavy, napríklad román Invalidni sourozenci („,katechizmus československého undergroundu“) mu vyšiel prvýkrát v Československu ${ }^{11}$ v roku 1991 v bratislavskom vydavatel'stve Archa s predhovorom košického disidentského filozofa Marcela Strýka, ${ }^{12} \mathrm{~s}$ ktorým boli v priatel'skom vztahu od osemdesiatych rokov.

6 K charakteru a parametrom slovenskej migrácie okolo roku 2000 pozri napríklad Divinský 2007: 101 a nasledujúce.

7 Český disident Miroslav Vodrážka píše v súvislosti s Bondyho celoživotnou sebaprezentáciou o sklone „k bájnému chvastounství a megalománii“ (Vodrážka 2020). Samozrejme, tieto črty Bondyho osobnosti boli intenzívnejšie pocitované v pražskom okruhu, ale možno ich zaznamenat aj v Bratislave. Podobne ako v iných jeho prózach existuje aj v Epizóde' 96 priama autobiografická referencia medzi sebavedomým a intelektuálne exkluzívnym rozprávačom a samotným Bondym. (Auto)naratív o neobyčajnej dôležitosti spisovatel'a a filozofa viacerí spájajú s Bondyho manipulatívnostou (M. Klečacká-Beyly, M. Vodrážka). Afirmatívne prijatie Bondyho v Bratislave sa prejavuje napríklad aj v grafickej úprave druhého vydania knihy Agónie - Epizóda (Epizóda v názve je tam už bez apostrofného označenia roku '96), do ktorého vydavatel'stvo Marenčin PT zaradilo fotografickú prílohu mapujúcu jeho spoločenský život v Bratislave. Ide o snímky z pravidelných stretnutí s tunajšími intelektuálmi a umelcami, ktoré sú zachytené aj v próze Epizóda (Albert Marenčin, Laco Teren, Dušan Dušek, Oleg Pastier a d'alší).

8 O niektorých detailoch spolupráce E. Bondyho a Plastic People bližšie Jirous 1997: 237-390.

9 K Bondyho hudobným aktivitám v Bratislave bližšie Beličová 2010: 61-79.

10 Ide predovšetkým o mal'bu Stana Bubána Banálna historka s charitatívnou zápletkou (Egon Bondy) (2002) a plastiku Juraja Bartusza Egon Bondy (2009/2010). Bubánova mal'ba s aktualizovaným námetom takzvanej rímskej charity sa objavila aj na obálke druhého vydania Agónie-Epizódy z roku 2015. Obe diela vo svojej štúdii analyzuje Eva Kopsová (Kopsová 2010: 283-296).

11 Prvé vydanie v torontskom exilovom vydavatel'stve Sixty-Eight Publishers pochádza z roku 1981.

12 K osobnosti M. Strýka (1955 - 1994) pozri napríklad heslo v Slovníku českých filosofi̊, dostupné online: www.phil.muni.cz/fil/scf/komplet/stryko.html 
Bondyho bratislavská novela Epizóda '96 vyšla prvýkrát knižne v roku 307 1997 vo Vydavatel'stve PT (v súčasnosti Marenčin PT) spolu s poviedkou Agónie datovanou rokom $1993 .{ }^{13}$ Úvodná Agónie je napísaná po česky, Epizóda '96 po slovensky s evidentnou lexikálnou a tvaroslovnou vrstvou češtiny. Jazyk tejto prózy by si zaslúžil osobitnú pozornost', teraz však nebude predmetom môjho záujmu. Len poznamenávam, že jazykový prestup českého autora z češtiny do slovenčiny síce nie je jav úplne ojedinelý, v relevantných prípadoch sa však udial u spisovatel'ov, ktorých so Slovenskom spojilo obdobie detstva a mladosti (dramatik Peter Zvon, prozaici Peter Jilemnický a Ladislav Mňačko). ${ }^{14}$ Bondyho prestup je v kontexte česko-slovenských jazykových vztahov a asymetrickej biliterárnosti ${ }^{15}$ zjavne politickým gestom a priamo súvisí s chápaním životného zmyslu v tejto próze, ktorý sa realizuje osobnou angažovanostou v konkrétnom priestore, aktívnym hladaním jeho „ducha“, a teda aj akceptovaním jeho (väčšinového) jazyka. ${ }^{16}$

Spojenie dvoch uvedených próz do jednej knihy nie je náhodné. Agónie je totiž ouvertúrou Epizódy '96, aj ked' tematicky čerpá z odlišnej, historickej látky. Próza má dve línie, súčasnú, zaplnenú Bondyho reflexiami postkomunistickej krajiny a jej, podla jeho chápania, dobového úpadku, druhá línia sa vracia do dôb neskoroantického intelektuála Sidonia (Sidonius Apollinaris, 430-489 n. 1.), súčasníka zániku Rímskej ríše a jej vzdelanosti na území vtedajšej Galie. Je to dôležitý moment pre interpretačný rámec Epizódy '96: kedysi vplyvný intelektuál z centra (Sidonius bol aj rímskym prefektom) je teraz svedkom aj obetou rozkladu civilizácie zanikajúcej pod náporom barbarov. Takto sa v poviedke Agónie pod tlakom kapitalizmu mení v očiach rozprávača aj dobová Praha, jej verejný priestor sa rýchlo devalvuje. Zmenu pomerov stelesňujú rastúci turizmus a agresívne podnikanie vo všetkých podobách, všadeprítomná reklama a prudký rast cien.

„Bufet zrušen. Kino taky. Krám s normálními potravinami v celém širokém areálu už ani jeden. Zato cestou ulicí desetkrát viděl Bohemia glass. Smrákalo se stále víc. Nebe zatažené, zde ovšem vždycky. Překontroloval, má-li klíče, peněženku a toaletní papír. Má to lepší jak Sidonius!" (Bondy 1997: 14)

Obe prózy spája aj úvodný motív cestovania do mesta, kde rozprávač žije a má materiálne aj citové zázemie. Kým však v Agónii sú s Prahou spojené už spomínané negatívne asociácie, príjazd do Bratislavy v Epizóde '96 je emocionálne iný, rozprávač je vo „svojej krajine“ a cíti „čudný stav bezpečia“ (Bondy 1997: 17). Podobne ako iné Bondyho prózy má aj Epizóda '96 fragmentárnu štruktúru.

13 Dobovú kritickú reflexiu knihy tvorili napríklad recenzie Adama Bžocha, Petra Darovca, Pavla Matejoviča, Jaroslava Vlnku, Jany Wild. Recenzenti napospol ocenili najmä reflexívne pasáže prózy a ich sebauvedomujúcu, ba až terapeutickú funkciu vo vztahu k mestu a jeho obyvatel'om (napríklad A. Bžoch $\mathrm{v}$ šiestom čísle $R A K$-u z roku 1997).

14 Kniektorým aspektom slovensko-českých jazykových vztahahov v oblasti umeleckej literatúry bližšie v kapitole Slovenčina a čeština v literárnom spolužití z knihy Miry Nábělkovej Slovenčina a čeština vkontakte: Pokračovanie príbehu (Nábělková 2008: 234-291).

15 K pojmu biliterárnost' bližšie napríklad Chmel 1985.

16 Išlo o jednorazový pokus. Bondy slovenčinu neovládal dostatočne a nemohla sa stat' jeho trvalým literárnym jazykom, nevyužil ju ani v d'alšej knižnej próze Týden v tichém městě (1998), ktorej dej čiastočne umiestnil do Bratislavy. 
308 Rámcom a zmyslotvorným činitel'om jednotlivých príbehov, motívov a historicko-filozofických reflexií s prvkami mystiky je samotný rozprávač, jeho intenzívne tostí, umožňující životní zařazení bytosti - zde lidské bytosti - do tohoto celku“ (Patočka 1991:16, zvýraznil J. P.).

Francúzsky urbanista Dominique Perrault sa v eseji v kolektívnej publikácii Bratislava metropolis sústreduje na jeden aspekt mestského priestoru, ktorý je interpretačne podnetný aj pri čítaní Bondyho bratislavskej prózy. Ide o „vniknutie krajiny do metropoly“ (Perrault 2013: 12). Perrault tvrdí, že „skúsenost's prázdnom v metropole oplýva možnostami. Môže byt' rovnako dobre synonymom znečistenia, vylúčenia alebo osamotenia, ako aj kolektívnou a spoločnou skúsenostou, pričom prázdno sa javí ako miesto otvorené prispôsobeniu a predstavivosti“" (Perrault 2013: 12). Literárna reprezentácia Bratislavy je u Bondyho ovplyvnená vedomím prázdna (hoci sám tento pojem explicitne nepoužíva) a je pokusom o imaginatívne kódovanie urbanistickej a krajinnej situácie mesta. Autor sa pýta, aký charakter má toto mesto, ${ }^{17}$ a sprostredkujúcou „rukolapnou“ skúsenostou, podnetom na túto otázku, je práve fenomén prázdna/prázdnoty, ktorý sa vo fyzickom organizme mesta objavuje v Bondyho texte v dvoch významoch:

1. Prázdno dané krajinne a urbanisticky, spôsobené napríklad odstupom mesta od Dunaja - autor totiž chápe rieku ako klúčový prvok génia loci nielen dunajských miest. Za podstatný urbanistický prvok Bratislavy, podla neho otočenej chrbtom, a nie celkom priatel'sky k Dunaju, považuje do mesta vnikajúce prostredie Malých Karpát s vinohradmi na ich južných svahoch. V tomto momente sa v Bondyho reflexiách „prázdno“ chápané ako prírodná krajina v meste prepája s historickou, tisícročnou tradíciou vinohradníckeho a remeselníckeho sídla a podobne ako odstup od rieky fundamentálne formuje ducha mesta. ${ }^{18}$

2. Prázdnota sa však prejavuje aj vo sfére l'udskej činnosti, je dôsledkom kultúrnej diskontinuity medzi pôvodným „mestom tisícročným“ a dokaličeným „novým mestom“- priestorom „zločinov [...] vraj vlasteneckých modernistických urbanistov“ (Bondy 1997: 24). Dokladom týchto „zločinov“ sú rozsiahle vybúrané časti intravilánu mesta, jeho cenných historických častí. Rozprávač Epizódy '96

17 „No toto moje mesto má kdesi skrytého ducha, akého inde niet, hoci o tom len málo jeho obyvatel'ov vie“" (Bondy 1997: 19).

18 Bondy pripisuje Dunaju klúčovú úlohu v pochopení génia loci Bratislavy. V slovenskej próze však Dunaj nepatrí k zvlášt vytaženým toposom (na rozdiel od romantickej poézie exponujúcej rieku ako jeden z národných symbolov). $\mathrm{V}$ súvislosti s Dunajom možno spomenút napríklad Kŕdel'divých Adamov Ladislava Ťažkého, Letnú nedelu Juraja Špitzera, Výlet na Devín Jána Roznera alebo Pentcho: príbeh parníka Jara Riháka. Do širšieho kontextu stredoeurópskej kultúrnej tradície situuje Bratislavu Claudio Magris vo svojom Dunaji. S Dunajom a Bratislavou je spojená aj memoárová cestopisná kniha britského autora Patricka Leigha Fermora A Time of Gifts (1977), súčast' trilógie opisujúcej autorovu cestu naprieč Európou do Istanbulu. Problematiku Dunaja ako miesta kultúrnej pamäti a literárnej reprezentácie Bratislavy na príkladoch Magrisa a Fermora v ostatnom čase teoreticky konceptualizoval Ch. Sabatos (Sabatos 2020). 
tematizuje najmä Most SNP, Vydricu a celé Podhradie ${ }^{19}$ a v inom kontexte aj 309 d'alšie, nové časti mesta:

„Na hlavnej triede medzi obyčajnými činžiakmi z prvej republiky prízemné domčeky niekdajších vinohradníkov - všetky rovnako ošarpané, čo nemožno zakryt'reklamami a neónmi, na ktorých takči takv noci svieti len každédruhépísmeno-tuzrazu krásny barokový dom a ohavný pseudogotický kostol obkolesený budovami ranej fázy budovania socializmu, o kúsok d'alej skutočne mohutnépaláce rozvinutého socializmu a opät'paneláková zástavba, vtom domčeky a ko na ozajstnej dedine a znova vežiak až do nebies, dost'vel'ký, gulatá veža a naokolo sa tak roztiahlo železničné depo, že musíš ist' kilometer, aby si sa mohol dostat' z jednej ulice do druhej“" (Bondy 1997: 81-82).

Tento typ prázdnoty je znakom a zároveň ,generátorom“ mentálnej situácie jeho obyvatel'ov v devätdesiatych rokoch, ktorá sa prejavuje v ,,ahistorickom“ a „nemestskom“ spôsobe života. Ten identifikuje rozprávač Epizódy '96 najmä v obraze sídliska Petržalka. Všíma si absenciu intímnejších mestských priestorov, zón susedskej komunikácie, krčiem, kostolov (!), kín či divadiel. Tu sa prázdno prejavuje ako prílišná perforácia mestského priestoru, ktorý má byt' nielen urbanisticky, ale aj sociálne, ludsky plný. Bondy asi prvý literárne zachytil Petržalku ako labyrint, v ktorom sa totalitná realizácia neskoromodernistických urbanistických vízií premietla do sociálne neúplného až retardovaného mestského celku. Disponuje však zvláštnou mágiou, pričom tento magický pocit je spôsobený jednak prírodným faktorom (leží za Dunajom, evokuje sa tu prekročenie hraníc dávnej rímskej provincie Panónia), ${ }^{20}$ no najmä labyrintickou štruktúrou sídliska. Interpretovi sa ponúka paralela s inými, neskoršími obrazmi Petržalky, ktoré tiež pracujú s motívmi priestorového labyrintu a z neho vyplývajúcich spoločenských dôsledkov (v románoch Daniela Heviera Kniha, ktorá sa stane, 2009, alebo Jany Beňovej Café Hyena. Plán odprevádzania, 2008).

Nemáme doklady o tom, že by Bondy poznal staršie literárne portréty tohto mesta, vidno teda, že metafora hranice a hraničnosti patrí k topologickým a tematologickým univerzáliám v zobrazovaní priestoru Bratislavy a viac ako evidovanie prítomnosti tohto motívu je zaujímavé sledovat jeho dobové transformácie a individuálne realizácie. Špecifikom Bondyho bratislavskej mimetickej topografie ${ }^{21} \mathrm{v}$ próze Epizóda '96 je fakt, že mesto nie je ani raz priamo pomenované. Konkrétne, reálne mená majú len jeho jednotlivé časti, ulice, objekty a podobne. Na viacerých miestach prózy ,presvitá“ ako hodnotový rámec jeho vnímania bratislavského verejného priestoru Praha, asi najvýraznejšie sa to prejaví práve vo flanérskej epizóde zasadenej do Petržalky. Na jednej z pochôdzok mestom rozprávač zasadne do sídliskovej krčmy, ktorá ho zaskočí svojou všestrannou hrubostou a nehostinnostou. Neznámy návštevník ho, celkom strateného, zavedie do inej, „pražskej“ krčmy, v ktorej sa magicko-labyrintický motív prepojí s kategóriou až meštiackej útulnosti, malebnosti: 

níky, kde nebola ani jedna lampa. Šiel som za ním z mláky do mláky, lebo teraz som naňho užbol odkázaný, nevedel som, kde som a kade odtialto preč. [...] Vošli sme. Príjemné teplo, rozsvietená izba, stoly s vidieckymi vzorovanými a úplne čistými obrusmi, pokoj, pritlmená hudba, poloprázdno, dlážka umytá, v rohu výčapný pult, hlavnýv elegantnej vestičke - Praha, tretia cenová skupina, nie štvorka [...] Ked'som to rozprával známym, nikto mi nechcel verit'a do dnešného dña mi neverí, Marina Čarnogurská je dokonca presvedčená, že som sa stal obetou líšok (tých čínskych, samozrejme) a videl som liščí palác, ktorýje cez deň len haldou na smetisku“" (Bondy 1997: 84).

Kompozícia Epizódy '96 je postavená na striedavom exponovaní dvoch časových rovín: prvá, dobovo aktuálna, má podobu reflexie devätdesiatych rokov 20. storočia s jej charakteristickými loci communes. Ilustratívne, až inštruktážne prozaické epizódy zachytávajú dobový obraz Bratislavy (postava IT technika a začínajúceho podnikatel'a pohybujúceho sa na hrane zákona aj za ňou, drogovo závislá mladá umelkyňa Veronika, postavy z umeleckého prostredia Michal a Laco), majú charakter denníkových záznamov a drobných glos. Žánrovo sa pohybujú na hrane umeleckej beletrie, populárnych žánrov (krimi, fantasy) a filozofickej eseje, a nie sú pevnejšie zretazené do jedného príbehu. Osnovou prózy je homodiegetický autobiografický rozprávač so snahou o hlbšie pochopenie nového životného priestoru, v ktorom sa ocitol a ktorý mu čoskoro poskytne magickú možnost' spojenia s minulost'ou a so silami dobra a zla. Prakticky sa to realizuje formou krátkych prechádzok, vykročení zo samoty bratislavského bytu, v ktorom žije rozprávač sám po smrti svojej partnerky Júlie (jeden z množstva autobiografických signálov prózy), ale aj počas dlhých priatel'ských či samotárskych flanérskych vychádzok z centra, cez sídliskový okruh mesta, až na jeho hranice do prírodného prostredia.

Bondyho rozprávač žije najmä v najužšom centre mesta, z priestorového hl'adiska sa jeho každodenný pohyb prakticky prekrýva s výskytom postáv románu Rivers of Babylon (1991), je jeho špecifickým dôvetkom v tom zmysle, že jedna línia rozprávania tiež zachytáva premenu ekonomických elít mesta prakticky v priamej časovej nadväznosti na fabulu Pištankovho románu. Pištankovu knihu možno z priestorového hl'adiska nazvat' románom interiérov (konceptuálna metaforika odkazujúcu na sociálnu transformáciu postavy Rácza sa realizuje „,vo vnútri“ a tradičným smerom zdola nahor, z kotolne a pivnice do vily nad mestom). Bondyho rozprávača spája s Ráczom jeho outsiderstvo, ktoré má úplne iný charakter, ale jeho potenciál je rovnaký: nazriet' na mesto novým spôsobom. Ciel'om však nie je ekonomicko-statusová exploatácia tohto poznania, jeho takpovediac rukolapná kapitalizácia. Bondy zostáva skôr pozorovatel'om a jeho sonda do dobovej Bratislavy je v tomto zmysle prózou exteriérov.

Druhú, zo žánrovo-tematického hl'adiska postmoderne ozvláštňujúcu vrstvu Epizódy '96, vytvára historická fantasy, situovaná do 18. storočia s postavami sochára Messerschmidta a bratislavského rabína, ktorí bojujú so zlým duchom ovládajúcim podhradie aj mesto.

Súbor búst Františka Xavera Messerschmidta, ktorý neskôr dostal názov Charakterové hlavy, zachytáva extrémne l'udské výrazy a grimasy. Vznikal z vel'kej časti v Bratislave (Prešporku), kde tento rakúsky sochár žil od roku 1777 až do svojej smrti v roku 1783. Už počas 18 . storočia busty vzbudzovali vel'ký záujem 
a podnecovali rôznorodé interpretácie. Messerschmidtov životný príbeh a jeho duševná, respektíve nervová choroba a Charakterové hlavy sú zdrojom rozličných dohadov, ${ }^{22}$ ale v súvislosti s psychickou chorobou a so schizofrenickým utrpením sa ich vznik interpretoval aj v minulosti. Busty mali byt' nástrojom vyslobodenia od „zlého ducha“ duševnej choroby. A práve tento moment Bondy uchopil ako iniciačný podnet línie historickej fantasy, ktorá nefunguje samostatne, ale len vd'aka citlivému aktualizačnému médiu, ktorým je sám rozprávač. Zjavovanie či hl'adanie ducha miesta nie je v Bondyho tvorbe novinkou, stačí uviest' text piesne Magické noci: „My žijemev Praze to je tam / kde se jednou zjeví Duch sám / My žijeme v Praze to je tam" (Plastic People of the Universe). Okrem tohto personalizovaného spojiva starého a nového (respektíve duchovného a materiálneho), ktoré dokáže pomenovat' ducha Bratislavy, je tu však aj ich priestorový priesečník.

Reflexie oboch časových rovín sa stretávajú v jednom klúčovom bratislavskom topose. Hradný kopec absorbuje jednotlivé historické naratívy počnúc Keltmi či Rimanmi, cez stredovek a tereziánske obdobie, totalitné režimy 20. storočia až po postsocialistickú súčasnost'. V jednej z epizód podnikne rozprávač s priatel'om Lacom pre čitatel'a inštruktážnu návštevu podzemného labyrintu, bývalého protiatómového krytu, vtedy povestného hudobného Sub-clubu v útrobách hradného kopca. Ten, ako znak novej nehostinnej doby, poskytuje priestor zlému duchovi, s ktorým na rovnakých miestach približne pred dvesto rokmi bojoval Messerschmidt: ${ }^{23}$ „Ked'sme sa rozlúčili, div že nie bozkom, ostal som ohúrený stát'. Taksme Zuckermantel konečne našli. Zlýduch nespal a urobil si také priestranné dúpä. Majstrov domček bol pre neho naozaj primaly" (Bondy 1997: 64).

Záverečná Bondyho interpretácia situácie Bratislavy na konci 20. storočia je otvorene antikapitalistická a tematicky ekvivalentná s poviedkou Agónie. Mení sa iba využitá historická situácia a namiesto Galie na konci staroveku sa paralela k súčasnosti hl'adá v bratislavských reáliách druhej polovice 18. storočia. Zlý duch zabil Messerschmidta, aby mu znemožnil dokončit' sériu jeho hláv, ktoré mali byt' obranou proti nemu, a teraz sa znovu zjavuje v meste v podobe reštaurácie divokého kapitalizmu. Základná časová perspektíva je tu teda „nedejinná“, vedomie rozprávača skôr ako s konkrétnym historickým časom pracuje s cyklickým plynutím, v ktorom opätovne dochádza k ekvivalentným súbojom princípov či ideí bez možnosti definitívneho rozhodnutia. „Čo zostane, bude vegetovanie, len lapanie po dychu, opät'len zápas o holé prežitie“ (Bondy 1997: 100).

Epizóda '96 je z vel'kej časti portrétom Bratislavy z obdobia divokého kapitalizmu prvej polovice devät'desiatych rokov 20. storočia, ale niektoré reflexie a pozorovania majú univerzálnejší charakter. Literárne aj myšlienkovo živá zostáva autorova citlivost' voči ambivalentnej a heterogénnej štruktúre tohto mesta. Charakterizuje ju napätie medzi starou vrstvou mesta a socialistickým urbanizmom obdobia neskorej moderny, ktoré sa v sociálno-psychologickom profile

22 O živote a diele F. X. Messerschmidta píše komplexne Mária Pötzl-Malíková (2004). Michal Maršálek interpretuje grimasy ako záznam dystónie, mimovolného stahovania svalov, ktoré spôsobuje ich abnormálny pohyb a pozície (Maršálek 2015).

23 Mágia bratislavského hradného kopca funguje aj v románe Viliama Klimáčka Nad'a má čas (2002), v ktorom električkový tunel pod kopcom plní úlohu magickej časovej slučky. 
312 obyvatel'ov prejavuje ahistorickým prežívaním v prítomnosti a stratou kultúrnej pamäti. Bondy jasne vnímal heterogénny a nekompaktný priestor mesta, zhluku historicky, urbanisticky aj kultúrne často nekompatibilných štruktúr, ako výraz jeho oslabenej identity. $\mathrm{V}$ tomto zmysle je messerschmidtovskou legendou dotovaný rozprávkový príbeh o ,zlom duchovi“ mesta funkčným apelatívom, hoci ústi do čisto ideologického antikapitalistického pamfletu v závere prózy.

Okrem dobovo podmienenej kritiky pomerov próza prináša flanérske reflexie slovenskej metropoly, v ktorých senzitívny autor nesporne prispel k beletristickému formulovaniu génia loci mesta, postaveného na nejednoznačnej a často protikladnej kvalite prázdnych miest v krajinno-prírodnom aj urbanisticko-kultúrnom zmysle slova a z nich vyplývajúcich psychologických a spoločenských dôsledkov pre jeho obyvatel'ov.

Štúdia je výstupom grantového projektu VEGA 2/0069/19 „Geopoetika“ Bratislavy: reprezentácie mesta $v$ slovenskej literatúre po roku 1918. Zodpovedný riešitel: Mgr. Radoslav Passia, Ph.D. Doba riešenia: 2019-2022.

\section{Pramene}

BONDY, Egon, 1997. Agónie-Epizóda '96. Bratislava: Vydavatel'stvo PT. ISBN 80-967686-1-1. BONDY, Egon, 1998. Týden v tichém městě. Bratislava: Vydavatel'stvo PT. ISBN 80-88912-01-6. JIROUS, Ivan Martin, 1997. Magorův zápisník. Praha: Torst. ISBN 80-7215-033-2.

KLEČACKÁ-BEYLY, Marie, 2008. Vzpomínky malostranské. Praha: Akropolis. ISBN 978$-80-86903-81-1$.

\section{Literatúra}

BELIČOVÁ, Renáta, 2010. Egon Bondy a slovenská hudobná postmoderna. In FEDROVÁ, Stanislava, ed. Česká literatura v intermediálni perspektivě. Praha: Ústav pro českou literaturu AV ČR- Nakladatelství Akropolis, s. 61-79. ISBN 978-80 87481-02.

DIVINSKÝ, Boris, 2007. Labor market - migration nexus in Slovakia: time to act in a comprehensive way. Bratislava: IOM Medzinárodná organizácia pre migráciu. ISBN 978-80-89158-17-1. HODROVÁ, Daniela, 2006. Citlivé město. Eseje z mytopoetiky. Praha: Akropolis. ISBN 80-86903-31-1.

HRBATA, Zdeněk, 2005. Prostory, místa a jejich konfigurace v literárním díle. In ČERVENKA, Miroslav, ed. Na cestě ke smyslu: Poetika literárního díla 20. století. Praha: Torst, s. 315-509. ISBN 80-7215-244-0.

CHMEL, Rudolf, 1985. Biliterárnost' a medziliterárne spoločenstvá. In ĎURIŠIN, Dionýz. Teória medziliterárneho procesu. Bratislava: Tatran, s. 221-223.

KAPSOVÁ, Eva, 2010. Podoby českých literátov v slovenskom vizuálnom kontexte: Prípad Bondy. In FEDROVÁ, Stanislava, ed. Česká literatura v intermediální perspektivě. Praha: Ústav pro českou literaturu AV ČR - Nakladatelství Akropolis, s. 283-296. ISBN 978-80-85778-73-1.

MARŠÁLEK, Michal, 2015. Dystonia in Art:The Impact of Psychiatric and Neurological Disease on the Work of the Sculptor F. X. Messerschmidt. In KANOVSKY, Petr-BHATIA, Kailash P.-ROSALES, Raymond L., ed. Dystonia and Dystonic Syndromes. Wien: Springier-Verlag, s. 227-242. ISBN 978-3-7091-1515-2.

NÁBĚLKOVÁ, Mira, 2008. Slovenčina a čeština v kontakte: Pokračovanie príbehu. Bratislava - Praha: Veda, vydavatel'stvo SAV - Jazykovedný ústav Ludovíta Štúra SAV - Filozofická fakulta Univerzity Karlovy v Praze. ISBN 978-80-224-1060-1.

NIŽŇANSKÝ, Eduard a kolektív, 2011. Stratené mesto. Bratislava: Marenčin PT. ISBN 978 -80-8114-108-9.

PATOČKA, Jan, 1991. Prostor a jeho problematika. Estetika, roč. 28, č. 1, s. 1-37. ISSN 0014$-1291$. 
PERRAULT, Dominique, 2013. Prázdno/Le vide. In Bratislava metropolis. Editori Michal

Bogár, L'ubomír Králik a L'udovít Urban. Bratislava: Spolok architektov Slovenska, s. 11-29. ISBN 978-80-88757-77-1.

PÖTZL-MALÍKOVÁ, Mária, 2004. F. X. Messerschmidt a záhada jeho charakterových hláv. Bratislava: Marenčin PT. ISBN 80-88912-74-1.

SABATOS, Charles, 2020. Bratislava as a cultural borderland in the Danubian narratives of Patrick Leigh Fermor and Claudio Magris. World Literature Studies, roč. 12, č. 4, s. 3-19. ISSN 1337-9275.

\section{Elektronické zdroje}

VODRÁŽKA, Miroslav: Strach z odkouzlení dějin (Bondy, Babiš, úlisnost teorie separátního subjektu a ideální publikum narativu). Praha: www.bubinekrevolveru.cz [online], 9. 3. 2020. Dostupné z: https://www.bubinekrevolveru.cz/strach-z-odkouzleni-dejin-bondy-babis-ulisnost-teorie-separatniho-subjektu-idealni-publikum-narativu

Mgr. Radoslav Passia, Ph.D.

Ústav slovenskej literatúry SAV

Dúbravská cesta 9

84104 Bratislava

Slovenská republika

E-mail: Radoslav.Passia@savba.sk 